\title{
The response of marigold (Tagetes erecta Linn.) to ozone: impacts on plant growth and leaf physiology
}

\author{
Ning Yang ${ }^{1,2} \cdot$ Xiaoke Wang $^{1} \cdot$ Feixiang Zheng $^{1,3} \cdot$ Yuanyuan Chen $^{1,2}$
}

Accepted: 20 November 2016 / Published online: 15 December 2016

(C) Springer Science+Business Media New York 2016

\begin{abstract}
Progressively increasing ozone $\left(\mathrm{O}_{3}\right)$ concentrations pose a potential threat to the value of marigold (Tagetes erecta Linn.), a plant widely used in urban landscaping. The response of marigold to elevated $\mathrm{O}_{3}$ has been reported earlier, but the mechanisms underlying the $\mathrm{O}_{3}$ effect have not been clearly elucidated. In the present study, we exposed marigold "Moonsong Deep Orange" plants to elevated $\mathrm{O}_{3}$, including ambient non-filtered air (NF) plus 60 $\mathrm{ppb}(\mathrm{NF}+60)$ and $120 \mathrm{ppb}(\mathrm{NF}+120) \mathrm{O}_{3}$, to assess visible injury and the possible physiological consequences of this pollutant. Yellow lesions appeared after 4 days under NF +120 treatment and 12 days under NF+60 treatment, with $85.6 \%$ and $36.8 \%$ of the leaves being injured at harvest time, respectively. Compared with $\mathrm{NF}, \mathrm{NF}+60$ inhibited leaf photosynthesis, stem-diameter growth, and biomass production significantly, while the parameters were decreased more by $\mathrm{NF}+120$. Although the stomatal conductance decreased under elevated $\mathrm{O}_{3}$ exposure, the $\mathrm{O}_{3}$ flux into leaves increased by $28.0-104.8 \%$ under $\mathrm{NF}+60$ treatment and 57.5-145.6\% under NF+120 treatment. The total ascorbic acid (ASA) content increased due to elevated $\mathrm{O}_{3}$ exposure, while the reduced ASA content did not, resulting in a decreased ratio of reduced to total ASA. A lower level
\end{abstract}

Feixiang Zheng

zhengfeixiang@caas.cn

1 State Key Laboratory of Urban and Region Ecology, Research Center for Eco-Environmental Sciences, Chinese Academy of Sciences, Beijing 100085, China

2 University of Chinese Academy of Sciences, Beijing 100049, China

3 Institute of Environment and Sustainable Development in Agriculture, Chinese Academy of Agricultural Sciences, Beijing 100081, China of jasmonic acid (JA) was observed under elevated $\mathrm{O}_{3}$ exposure. In conclusion, the impacts of elevated $\mathrm{O}_{3}$ on marigold plants may be ascribed to increased $\mathrm{O}_{3}$ flux into leaves and reduced protective capacity of leaves to convert oxidized to reduced ASA and synthesize endogenous JA.

Keywords Ascorbic acid · Biomass · Jasmonic acid · Marigold $\cdot$ Ozone $\cdot$ Stomatal aperture

\section{Introduction}

Owing to rapid industrialization and urbanization, tropospheric ozone $\left(\mathrm{O}_{3}\right)$ concentration is thought to be increasing by $0.5-2 \%$ per year in the northern hemisphere based on predictive models (ICPP 2013). The average ambient $\mathrm{O}_{3}$ concentration in the northern hemisphere is expected to rise to approximately $42-84 \mathrm{ppb}$ (depending on space and time) by 2100 (Vingarzan 2004). Values exceeding 40 ppb will result in visible and invisible injuries to plants (Ashmore 2005) and will have detrimental effects on forests (Broadmeadow 1998), crops (Bao et al. 2014), and grasslands (Evans and Ashmore 1992). $\mathrm{O}_{3}$ attenuates photosynthesis, resulting in reduced carbon accumulation (Ainsworth et al. 2012; Sun et al. 2014). Furthermore, $\mathrm{O}_{3}$ accelerates leaf senescence and decreases leaf longevity by inducing injury (Zhang et al. 2011), which not only depresses plant productivity, but also affects their ornamental performance in human settlements.

As $\mathrm{O}_{3}$ enters plant leaves through stomata, these small organs represent the first line of defense and the principal interface responsible for $\mathrm{O}_{3}$ exchange between leaves and the atmosphere (Fares et al. 2014). Stomatal conductance controls $\mathrm{O}_{3}$ uptake by leaves. Studies have demonstrated that $\mathrm{O}_{3}$ stress reduces stomatal conductance (Sun et al. 2014) or stomatal aperture (Frey et al. 1996), resulting in 
reduced $\mathrm{O}_{3}$ flux into leaves and less $\mathrm{O}_{3}$-induced injury (Pääkkönen et al. 1996). However, opposite results have also been reported, i.e., plants exposed to $\mathrm{O}_{3}$ had a slower stomatal response to this pollutant and a weaker ability to close their stomata than the control (Hoshika et al. 2014). These inconsistent results require further investigation into the responses of various plant species to different $\mathrm{O}_{3}$ levels.

Ascorbic acid (ASA), the primary antioxidant scavenger of $\mathrm{O}_{3}$, functions in the detoxification of $\mathrm{O}_{3}$ in the leaf apoplast. Burkey et al. (2006) indicated that more reduced ASA is present in $\mathrm{O}_{3}$-insensitive plants than in $\mathrm{O}_{3}$-sensitive ones, with a lower percentage of $\mathrm{O}_{3}$ injury detected in the former than the latter. However, other studies have suggested that ASA cannot be a primary $\mathrm{O}_{3}$ scavenger because the level of reduced ASA in the leaf apoplast is substantially low (Booker et al. 2012). Hence, it is questionable whether ASA levels represent an effective index for assessing $\mathrm{O}_{3}$ injury in plants. In fact, only a portion of the $\mathrm{O}_{3}$ entering leaves participates in the reaction with ASA; another portion of $\mathrm{O}_{3}$ remains to attack the plasma membrane and cause membrane lipid peroxidation, as well as influence phytohormone biosynthesis (Zhao et al. 2013).

Phytohormones function as second messengers in oxidative signal transduction; they regulate signal strength either alone or together (Baier et al. 2005). Jasmonic acid (JA) is a key signaling compound that functions in the plant response to stress (Wasternack 2014), and its roles in containing lesion propagation (Pellegrini et al. 2013) and protein storage (Creelman and Mullet 1997) are widely known. JA biosynthesis begins in the chloroplast, where linolenic acid is converted into hydroperoxylinolenic acid by lipoxygenases (Bartoli et al. 2013). JA-insensitive mutants and mutants blocked in JA biosynthesis could develop lesions under elevated $\mathrm{O}_{3}$ exposure (Rao et al. 2000), demonstrating that JA can reduce $\mathrm{O}_{3}$-induced injury to plants. However, less is known about whether $\mathrm{O}_{3}$ injury to plants is driven by $\mathrm{O}_{3}$-induced changes in endogenous JA content.

Marigold (Tagetes erecta Linn.), a member of the Asteraceae family (Dasgupta et al. 2012), is widely cultivated in China. Marigold is native to Mexico, and its natural range extends from the Southeastern United States to Argentina. Marigold is well-known for a wide range of pharmacological, agricultural and industrial uses (Hussain et al. 2011; Maity et al. 2011; Nikkon et al. 2011). This species is also a common ornamental plant (bearing bright yellow and orange flowers) that is often used for decorative purposes (Kiranmai et al. 2011). As early as in the 1980s, marigold was found to be moderately sensitive to $\mathrm{O}_{3}$ when exposed to $300 \mathrm{ppb} \mathrm{O}_{3}$ (Sanders and Reinert 1982; Reinert and Sanders 1982). However, less is known about the physiological mechanisms of the ozone effect on marigold growth.
In this study, we chose marigold, a typical urban greening plant with a short life cycle, to investigate its growth response to elevated $\mathrm{O}_{3}$ exposure and the underlying physiological mechanisms. The objectives of the study were to investigate (1) the stomatal response of marigold to elevated $\mathrm{O}_{3}$ by measuring stomatal conductance (gas exchange) and stomatal movement (aperture and density); (2) whether $\mathrm{O}_{3}$-induced changes in stomatal conductance affect $\mathrm{O}_{3}$ uptake by calculating $\mathrm{O}_{3}$ flux into leaves of marigold; and (3) the defensive mechanisms of marigold plants by analyzing the capacity of leaves to synthesize ASA and JA and convert oxidized to reduced ASA.

\section{Materials and methods}

\section{Experimental site}

The experimental site was located in Zhangtou village $\left(40^{\circ}\right.$ $12^{\prime} \mathrm{N}, 116^{\circ} 8^{\prime} \mathrm{E}$ ), Changping district, Beijing, China. Beijing has a typical temperate, monsoonal climate, with four clearly distinct seasons. During the experimental period (4 August-28 September 2014), the average temperature, maximum temperature, and total precipitation were $22.6^{\circ} \mathrm{C}$, $28.1^{\circ} \mathrm{C}$, and $36.1 \mathrm{~mm}$, respectively. The monthly averages of background $\mathrm{O}_{3}$ concentrations were 51.6 and $51.0 \mathrm{ppb}$ in August and September 2014, respectively. According to data from the nearby air monitoring station (Beijing Urban Ecosystem Research Station), the average of all hourly averages $(24 \mathrm{hr} /$ day $)$ and peak one hourly average for $\mathrm{SO}_{2}$ concentrations were 3.1 and $17.4 \mathrm{ppb}$ in August and 5.9 and $21.5 \mathrm{ppb}$ in September 2014, respectively; the average of all hourly averages and peak one hourly average for $\mathrm{NO}_{2}$ concentrations were 3.8 and $21.6 \mathrm{ppb}$ in August and 9.5 and $47.1 \mathrm{ppb}$ in September 2014, respectively.

\section{Open top chambers}

Open top chambers (OTCs) were designed as previously described (Zheng et al. 2011a) with slight modifications. Regular dodecagon OTCs $(2.8 \mathrm{~m}$ in height and $4.0 \mathrm{~m}$ in diameter) were constructed from an aluminum alloy frame covered with stalinite (toughened glass). Ambient air or $\mathrm{O}_{3}$ was delivered by a centrifugal blower $\left(2800 \mathrm{r} \min ^{-1}\right)$ through PVC pipes with an internal diameter of $110 \mathrm{~mm}$, followed by release from driven-rotating acrylic tubes with downward-facing holes. The OTCs were placed $3 \mathrm{~m}$ apart. $\mathrm{O}_{3}$ was generated from pure oxygen with an $\mathrm{O}_{3}$ generator (HY003, Chuangcheng Co., Jinan, China) using high voltage discharge. The $\mathrm{O}_{3}$ concentration within the OTCs was monitored via an $\mathrm{O}_{3}$ analyzer (Model 49i, Thermo Scientific, Waltham, MA, USA) equipped with a flash memory to store the measurement data online. The Thermo iPort 
Fig. 1 Nine-hour mean ozone $\left(\mathrm{O}_{3}\right.$, vertical bar chart $)$ and daily peak $\mathrm{O}_{3}$ (line plot) concentrations in open top chambers during the experimental period (4 August-28 September 2014). $\mathrm{NF}, \mathrm{NF}+60$, and $\mathrm{NF}+120$ indicate the ambient control (non-filtered air) and two elevated $\mathrm{O}_{3}$ treatments (nonfiltered air plus $60 \mathrm{ppb} \mathrm{O}_{3}$ and $120 \mathrm{ppb} \mathrm{O}_{3}$ ), respectively

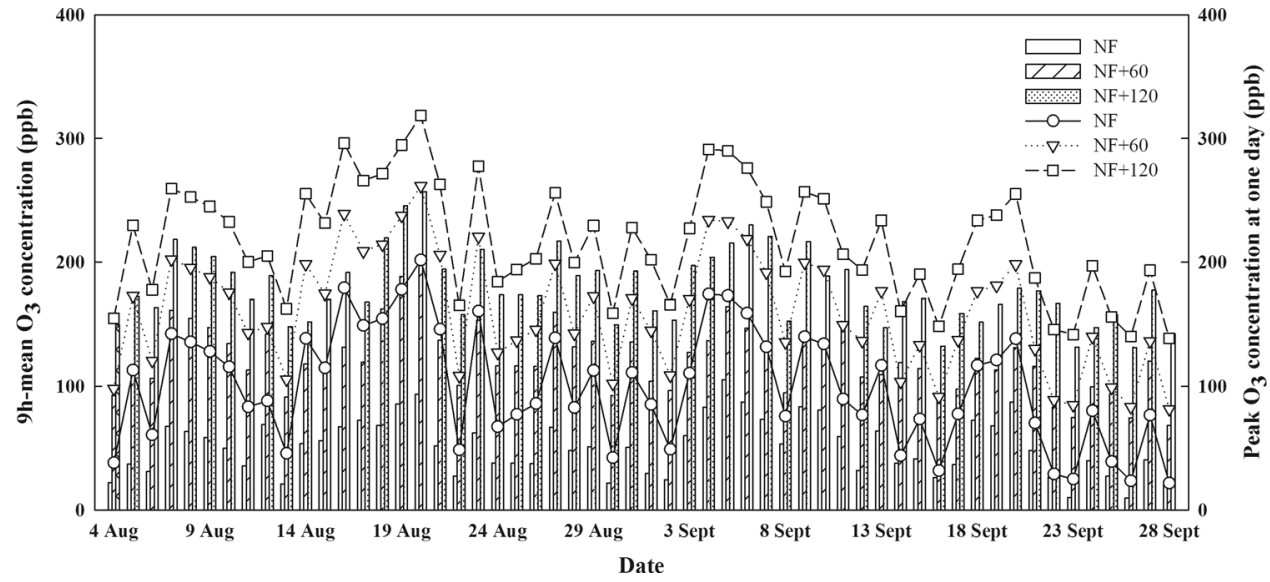

software was installed on a computer connected with $\mathrm{O}_{3}$ analyzer to download data weekly. The $\mathrm{O}_{3}$ analyzer was calibrated using a 49i-PS calibrator (Thermo Scientific), before the experiment and once a month during the experimental period. To attenuate chamber effects, OTCs were arranged in a line from south to north to ensure uniform environmental conditions, including solar radiation.

\section{Ozone treatment}

Three treatments were applied: non-filtered air (NF, control), non-filtered air plus $60 \mathrm{ppb} \mathrm{O}_{3}(\mathrm{NF}+60)$, and nonfiltered air plus $120 \mathrm{ppb} \mathrm{O}_{3}(\mathrm{NF}+120)$, with a single OTC per treatment. The plants were exposed to elevated levels of $\mathrm{O}_{3}$ for $9 \mathrm{~h}(8: 00 \mathrm{am}-17: 00 \mathrm{pm})$ every day from 4 August to 28 September 2014, except when it was raining. The door of chambers always opened at other time of the day for air exchange with the outside. The daily average of $9 \mathrm{~h}$ averages and daily peak one hourly average for $\mathrm{O}_{3}$, and accumulated exposure above a threshold of $40 \mathrm{ppb}$ (AOT40) based on 9-h $\mathrm{O}_{3}$ exposure period per day from fumigation beginning to the key periods for each treatment are shown in Fig. 1 and Table 1.

\section{Plant management}

A hybrid, male-sterile marigold cultivar (Tagetes erecta Linn. "Moonsong Deep Orange") seedlings of approximately $7.0 \mathrm{~cm}$ in plant height and $4.0 \mathrm{~mm}$ in stem diameter were purchased from Jindetai Landscape Engineering Co. (Beijing, China). The plants were subsequently moved into larger pots $(17.0 \mathrm{~cm}$ in height and $22.0 \mathrm{~cm}$ in diameter). One pot was allocated per plant, and 20 pots per treatment were used in each treatment. The substrate, which was purchased from the same company as the marigold seedlings, comprised a mixture of grass charcoal, vermiculite and perlite at a ratio of 100:1:2. Given the higher temperatures in the summer, the plants were watered with $900-1000 \mathrm{~mL}$ of tap
Table 1 Accumulated ozone exposure above a threshold of $40 \mathrm{ppb}$ (AOT40, ppm h) during key periods for different treatments (including the time of injury recording and physiological index determination)

\begin{tabular}{lccc}
\hline Date & NF & NF+60 & NF+120 \\
\hline 8 August & 1.3 & 3.9 & 6.4 \\
15 August & 2.6 & 8.6 & 14.2 \\
22 August & 5.8 & 15.4 & 24.6 \\
27 August & 7.4 & 19.6 & 31.3 \\
10 September & 11.3 & 30.5 & 49.2 \\
12 September & 11.7 & 32.1 & 51.7 \\
17 September & 23.7 & 67.1 & 108.5 \\
28 September & 25.1 & 73.0 & 119.9 \\
\hline
\end{tabular}

Note: $N F, N F+60$ and $N F+120$ represent non-filtered air and nonfiltered air plus $60 \mathrm{ppb} \mathrm{O}_{3}$ and $120 \mathrm{ppb} \mathrm{O}_{3}$, respectively

water after 17:00 pm every day when $\mathrm{O}_{3}$ treatment was stopped. Additionally, the replicates were not true independent units, i.e., chambers, but were individual pots within a chamber, so we rotated pots to minimize any pseudoreplication effects: the plant position within individual OTCs was changed every 3-5 days, the plants and $\mathrm{O}_{3}$ treatments were rotated among three OTCs every 10-15 days in order to minimize any individual chamber effects on growth. At each time of change among OTCs, the plants were first removed from the OTC; after the $\mathrm{O}_{3}$ concentration was reassigned, the plants were rearranged into a random OTC where they continued to receive the same $\mathrm{O}_{3}$ treatment as before (Feng et al. 2011a).

\section{Leaf injury assays}

Whole-plant and foliar injury were assessed every 7 days from 15 August to 28 September for 20 plants per treatment. All plants were observed macroscopically. For each plant, the percentage of injured leaves was quantified. Additionally, the percentage of injured area for each leaf was estimated according to six non-proportional classes, 
and the leaf injury index (LII) was then calculated as described previously (Furlan et al. 2007):

$$
\begin{aligned}
& \mathrm{LII}(\%) \\
& =\frac{(\mathrm{N} 1 \times 1)+(\mathrm{N} 2 \times 2)+(\mathrm{N} 3 \times 3)+(\mathrm{N} 4 \times 4)+(\mathrm{N} 5 \times 5)}{(\mathrm{N} 0+\mathrm{N} 1+\mathrm{N} 2+\mathrm{N} 3+\mathrm{N} 4+\mathrm{N} 5) \times 5} \\
& \quad \times 100
\end{aligned}
$$

where N0, N1, N2, N3, N4, and N5 are the number of leaves with zero, first, second, third, fourth, and fifth degree symptoms of $\mathrm{O}_{3}$ injury, respectively. The degree of symptoms was represented as follows: 0: no symptoms; 1: $0-5$; $2: 6-25 ; 3: 26-50 ; 4: 51-75$; and $5:>75 \%$ of foliar area with symptoms.

\section{Growth, biomass and photosynthesis measurements}

Sixty marigold seedlings with similar plant height and stem diameter were selected and equally distributed to the three treatments. At the beginning of the experiment, we marked the main stem of all plants at the substrate level. The initial plant height was measured from the marked position to the apex of the main stem and the initial stem diameter was measured at the marked position. During the experimental period, plant height and stem diameter were measured twice a month. To exclude the individual differences in marigold seedlings, the relative growth was calculated as the percentage increase in plant height and stem diameter compared with the last measurement. On 28 September, five plants per chamber were randomly harvested and separated into four components: leaves, flowers, stems, and roots. All parts were oven-dried at $80^{\circ} \mathrm{C}$ to achieve a constant weight for biomass measurements (Zhang et al. 2011).

Net photosynthetic rate and stomatal conductance of fully expanded sun leaves were measured twice in situ, respectively, at pre-anthesis (22 August) and anthesis (12 September), with an Li-6400 portable system (Li-Cor Inc., Lincoln, NE, USA). Five plants per chamber were randomly selected and one leaf per plant was measured. The Li-6400 system controlled saturating photosynthetic photon flux density at $1,500 \mathrm{mmol} \mathrm{m}^{-2} \mathrm{~s}^{-1}$ and $\mathrm{CO}_{2}$ at $400 \mathrm{ppm}$ using pure $\mathrm{CO}_{2}$ supplied by a cylinder. Measurements of net photosynthetic rate and stomatal conductance were conducted simultaneously, from 10:00 am to $12: 00 \mathrm{pm}$, when maximum parameters were generally reached (Zhang and Gao 1999; Grantz et al. 2013). Data were stored in the Li6400 system. $\mathrm{O}_{3}$ flux into leaves $\left(\mathrm{F}_{\mathrm{st}}\right)$ was calculated based on the following formula ( $\mathrm{Hu}$ et al. 2015):

$\mathrm{F}_{\mathrm{st}}=\left[\mathrm{O}_{3}\right] \times \mathrm{g}_{\mathrm{O}_{3}}$

where $\left[\mathrm{O}_{3}\right]$ is the $\mathrm{O}_{3}$ concentration and $\mathrm{g}_{\mathrm{O}_{3}}$ is the stomatal conductance of water vapor multiplied by 0.663 .

\section{Stomatal aperture and density analysis}

Stomatal characteristics were measured as described previously (Wen et al. 2014) with minor modifications. Four fully expanded sun leaves per plant and five plants per treatment were harvested at about 16:00 pm when daily peak ambient $\mathrm{O}_{3}$ concentrations occurred (Chen et al. 2015) on two occasions (pre-anthesis [22 August] and anthesis [12 September]). The fresh leaves were subsequently wiped with a wet towel and immediately placed into a $50-\mathrm{mL}$ white plastic bottle containing a fixative solution $(70 \%$ ethanol: glacial acetic acid: formalin [v:v:v $=90: 5: 5])$ to protect leaf cell structure from deformation. One day later, each leaf sample was cut into $1.0 \times 0.5 \mathrm{~cm}$ fragments and dehydrated in an ethanol gradient of 75, 85, 95, 100, and $100 \%$ ethanol at a time interval of $20 \mathrm{~min}$. After dehydration, each sample was incubated overnight in isoamyl acetate. The samples were then critical point dried, mounted on stubs, and coated with gold in a high-vacuum evaporation unit, followed by examination under a scanning electron microscope (FE-SEM-EDS, SU-8020, Hitachi, Tokyo, Japan) at $3.0 \mathrm{kV}$ acceleration voltage.

Stomatal aperture in the abaxial epidermis was determined microscopically by measuring the width of the inner lips of a minimum of 60 stomata per treatment from photographs captured using Image-Pro Plus 6.0 software (Media Cybernetics Inc., Rockville, MD, USA). Stomatal density was determined by manual counting using the convention of excluding stomata overlapping the margins of the image and was converted to the number of stomata per $\mathrm{mm}^{2}$ of abaxial leaf surface (Wen et al. 2014).

\section{Malondialdehyde, soluble protein and ascorbic acid measurements}

Fully expanded sun leaves were sampled for plant physiological measurements on three occasions: pre-anthesis (22 August), anthesis (12 September) and harvest (28 September). Five plants per chamber and one leaf per plant were sampled randomly. The leaves were wrapped in aluminum foil, frozen in liquid nitrogen, and stored in a $-80^{\circ} \mathrm{C}$ freezer before analysis.

Malondialdehyde (MDA) was determined by microplate spectrophotometer (Molecular Devices, USA) using 2-thiobarbituric acid-reactive metabolite (Feng et al. 2011b). MDA concentrations were calculated using the following equation: MDA concentration $\left(\mu \mathrm{mol} \mathrm{L}^{-1}\right)=6.45$ $\left(A_{532}-A_{600}\right)-0.56 A_{450}$, where $A_{450}, A_{532}$, and $A_{600}$ represent the absorbance of the reaction solution at 450,532 , and 600 $\mathrm{nm}$, respectively. MDA levels $\left(\mathrm{nmol} \mathrm{g}{ }^{-1}\right.$ ) were then normalized to fresh leaf mass, as determined by weighing before extraction. 
Soluble proteins were extracted by homogenizing $50 \mathrm{mg}$ of leaf tissue in $5 \mathrm{~mL}$ of phosphate buffer $(50 \mathrm{~mm}, \mathrm{pH} 7.8)$ with a prechilled mortar and pestle. After centrifugation at $3000 \mathrm{~g}$ for $10 \mathrm{~min}$ at $4{ }^{\circ} \mathrm{C}$, the absorbance of a mixture containing $1 \mathrm{~mL}$ of supernatant and $5 \mathrm{~mL}$ of Brilliant Blue G-250 at $595 \mathrm{~nm}$ was measured. Quantification of soluble proteins was carried out according to the Bradford (1976) method, with albumin bovine used as a standard.

Ascorbic acid was measured as described by Gillespie and Ainsworth (2007) but with a sample weight of $100 \mathrm{mg}$ fresh tissue. Total and reduced ASA levels were calculated based on a standard curve prepared using L-ascorbic acid (Sigma-Aldrich, St. Louis, MO, USA). The ASA redox state was indicated by the ratio of reduced to total ASA content.

\section{Jasmonic acid determination}

Jasmonic acid was extracted as reported previously (Pan et al. 2010), with minor modifications. Each $50 \mu \mathrm{L}$ extract sample was injected into a reverse-phase $\mathrm{C}_{18}$ highperformance liquid chromatography (HPLC) column (4.6 $\mathrm{mm} \times 5 \mathrm{~cm}, 1.8 \mu \mathrm{m}$ ) for HPLC-ESI-MS/MS (AB Qtrap 5500) analysis. The HPLC-ESI-MS/MS settings were as follows: source, turbo spray; ion polarity, negative; needle voltage, $-4500 \mathrm{~V}$; source temperature, $600{ }^{\circ} \mathrm{C}$; gas, nitrogen; curtain gas, 30 psi; nebulizing gas (GS1), 40 psi; focusing gas (GS2), 50 psi; interface heater, on; collision activated dissociation gas pressure, medium; and scan type, multiple reaction monitoring. The mobile phases included acetonitrile (A) and distilled water containing $0.1 \%$ acetic acid (B). Separations were performed by altering the percentage of B as follows: $90 \% \mathrm{~B}$ at $0-0.5 \mathrm{~min}, 95 \% \mathrm{~B}$ at 0.5-5 min and $90 \% \mathrm{~B}$ at 5-8 min to stabilize the instrument. JA concentration $\left(\mathrm{ng} \mathrm{mL}^{-1}\right)=($ concentration of internal standard $\times$ peak area of JA)/peak area of internal standard in that sample. JA levels (ng $\mathrm{g}^{-1}$ ) were then normalized to fresh leaf mass, as determined by weighing before extraction.

\section{Statistical analysis}

Prior to analysis, the original data were checked for normality (one-sample Kolmogorov-Smirnov test) and homogeneity of variance. Plant growth and physiological parameters were measured for all or five plants as replicates within each chamber. That if there was a significant interaction between ozone and time, we used One-Way analysis of variance (ANOVA) to analyze the data for ozone effects within a time, followed by Fisher LSD post-hoc test. We also examined the relationship between LII and AOT40 using linear regression analysis. The statistical significance was accepted at $P \leq 0.05$. Statistical analyses were performed using SPSS 16.0 (SPSS Inc., Chicago, IL, USA).

\section{Results}

\section{Leaf injury}

$\mathrm{O}_{3}$-induced yellowing lesions first occurred between the veins on the upper surfaces of marigold leaves (Fig. 2a). After 4 days of $\mathrm{O}_{3}$ exposure, leaf yellowing was detected on the bottom leaves under NF+120 treatment (Fig. 2b), with AOT40 of 6.4 ppm h (Table 1). After 12 days $\mathrm{O}_{3}$ exposure, leaf yellowing was detected under NF+60 treatment with AOT40 of $8.6 \mathrm{ppm}$ h (Table 1). Almost all foliar surfaces were covered with yellow lesions after 55 days of $\mathrm{O}_{3}$ treatment (Figs. 3a, b). The percentage of injured leaves and the LII significantly increased under $\mathrm{O}_{3}$ treatment (Figs. 3a, b) from the beginning of observation on 15 August, when the AOT40 was 2.6, 8.6 and $14.2 \mathrm{ppm}$ h for NF, NF+60 and $\mathrm{NF}+120$, respectively (Table 1). After 55 days of $\mathrm{O}_{3}$ exposure, only $19.5 \%$ of the leaf area was affected under $\mathrm{NF}$ treatment, whereas $\mathrm{NF}+60$ and $\mathrm{NF}+120$ treatments produced injured leaf areas of 36.8 and $85.6 \%$, respectively. A significant linear relationship was detected between LII and AOT40 based on observations made on the six sampling dates (Fig. 3c), suggesting that $\mathrm{O}_{3}$ injury to marigold leaves increased with increasing $\mathrm{O}_{3}$ exposure.

\section{Photosynthesis, growth and biomass}

Elevated $\mathrm{O}_{3}$ exposure suppressed leaf net photosynthetic rate in marigold plants at the pre-anthesis and anthesis stages, with reductions of 34.1 and $16.5 \%$ under $\mathrm{NF}+60$ treatment and 67.5 and $42.2 \%$ under NF+120 treatment, respectively (Fig. 4a). The relative increase in stem diameter was reduced by $16.7-30.7 \%$ under $\mathrm{NF}+60$ treatment and 37.0-46.3\% under NF+120 treatment (Fig. 4b); however, no significant changes were detected in the relative increase in plant height after elevated $\mathrm{O}_{3}$ exposure (Fig. 4c). $\mathrm{NF}+60$ treatment was sufficient to inhibit the increase in marigold biomass, with a $28.9 \%$ reduction detected by the end of the experiment. A greater reduction $(40.4 \%)$ in biomass was detected under NF+120 treatment (Fig. 4d).

\section{Stomatal traits and $\mathrm{O}_{3}$ flux}

Stomatal conductance and $\mathrm{O}_{3}$ flux, as well as stomatal aperture and density, were analyzed at both pre-anthesis and anthesis (Fig. 5). Stomatal conductance and stomatal aperture showed different responses to $\mathrm{O}_{3}$ stress, with a 27.2-67.4\% decline in the former (Fig. 5a) and a 29.1-121.7\% increase in the latter (Fig. 5b). 
Fig. 2 Foliar (a) and wholeplant (b) injury in marigold under different ozone levels. Treatment abbreviations are as in Fig. 1
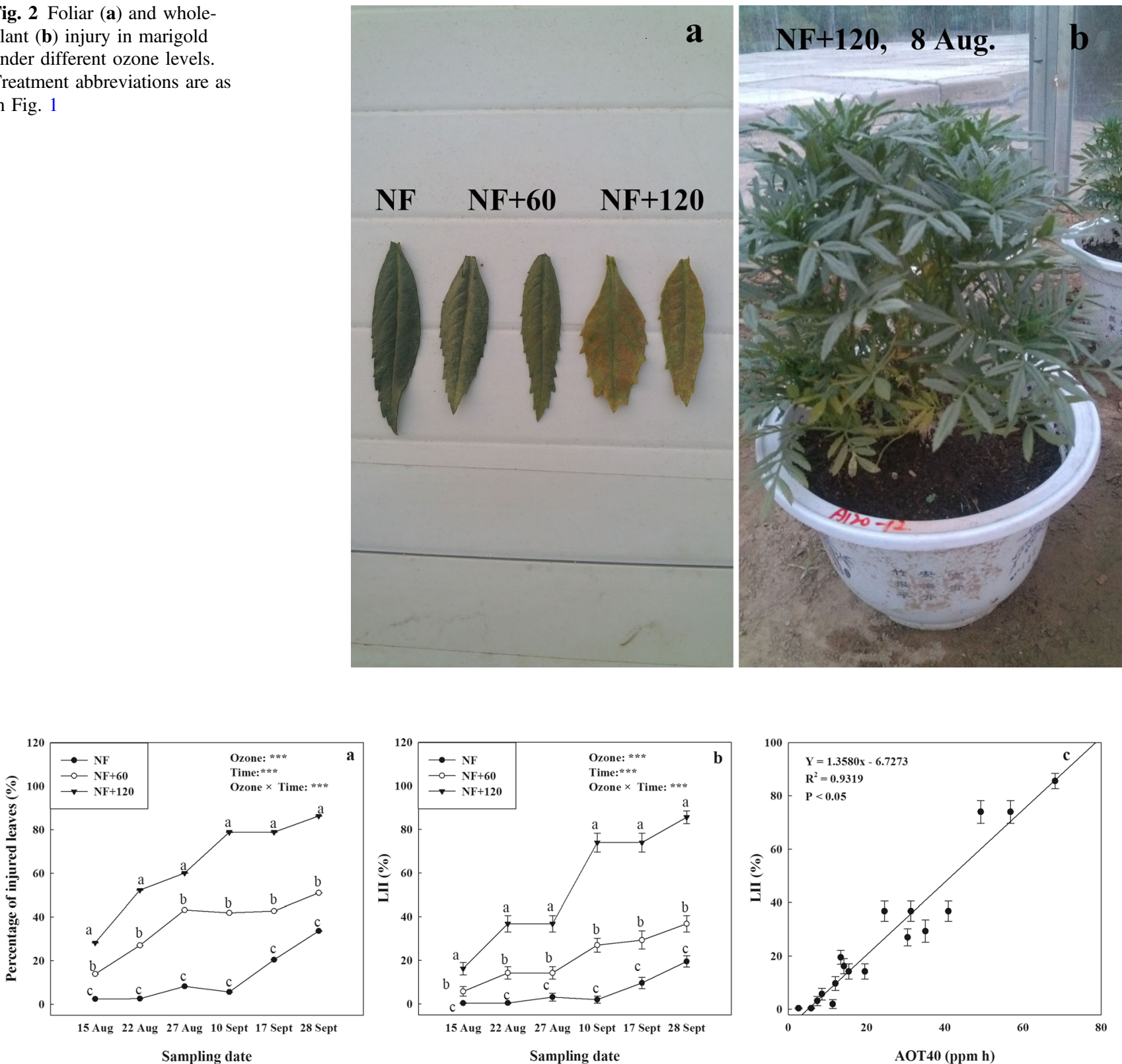

Fig. 3 The percentage of injured leaves (a), leaf injury index (LII, b), and relationship between LII and accumulated ozone exposure above a threshold of $40 \mathrm{ppb}$ (AOT40, c) in marigold under different ozone levels. Treatment abbreviations are as in Fig. 1. Data in $\mathbf{a}$ and $\mathbf{b}$ are shown as mean \pm standard error $(n=20)$. For each parameter, results

of one-way repeated measures ANOVA are reported, with asterisks showing the significance of factors (ozone and time) and their interaction for: $* * * P \leq 0.001$. Different lowercase letters indicate significant differences between the ambient control (NF) and elevated $\mathrm{O}_{3}$ treatments $(\mathrm{NF}+60$ and $\mathrm{NF}+120)(P \leq 0.5)$

Stomatal conductance exhibited stronger responses to higher $\mathrm{O}_{3}$ exposure than to lower $\mathrm{O}_{3}$ exposure, while aperture responses to both higher and lower $\mathrm{O}_{3}$ exposure were not significantly different based on the statistical analysis. No significant difference was detected in stomatal density between $\mathrm{NF}$ and elevated $\mathrm{O}_{3}$ treatments (Fig. 5c). The $\mathrm{O}_{3}$ flux into leaves showed an increase of 28.0-104.8\% under $\mathrm{NF}+60$ treatment and $57.5-145.6 \%$ under $\mathrm{NF}+120$ treatment, compared with the control (Fig. 5d).

\section{Malondialdehyde and soluble protein contents}

Elevated $\mathrm{O}_{3}$ exposure accelerated membrane lipid peroxidation in marigold leaves, as indicated by an increase in MDA contents (Fig. 6a). After elevated $\mathrm{O}_{3}$ exposure, the MDA contents at pre-anthesis, anthesis, and harvest significantly increased, with values of $83.7,50.2$, and $17.3 \%$ higher, respectively, under NF+60 treatment and 73.1, 50.1, and 21.4\% higher, respectively, under $\mathrm{NF}+120$ treatment. Elevated $\mathrm{O}_{3}$ treatment 
Fig. 4 Leaf photosynthetic rate (a) 10:00-12:00 am on 22 August and 12 September), plant growth expressed as percentage increase in stem diameter and plant height (b and c, 22 August, 5 September, 28 September, and 10 October), and biomass (d, 28 September) in marigold under different ozone levels. The reference for each measurement date of relative stem height and diameter was the value from the previous date. Treatment abbreviations are as in Fig. 1. Data are shown as mean \pm standard error $\left(n_{\mathrm{a}}=n_{\mathrm{d}}=5, n_{\mathrm{b}}=\right.$ $n_{\mathrm{c}}=20$ ). For growth and photosynthetic parameters, results of one-way repeated measures ANOVA are reported, with asterisks showing the significance of factors (ozone and time) and their interaction for: $* * * P \leq 0.001, * P \leq 0.05$, ns $=P>0.05$. Different lowercase letters indicate significant differences between the ambient control (NF) and elevated $\mathrm{O}_{3}$ treatments $(\mathrm{NF}+60$ and $\mathrm{NF}$ $+120)(P \leq 0.5)$
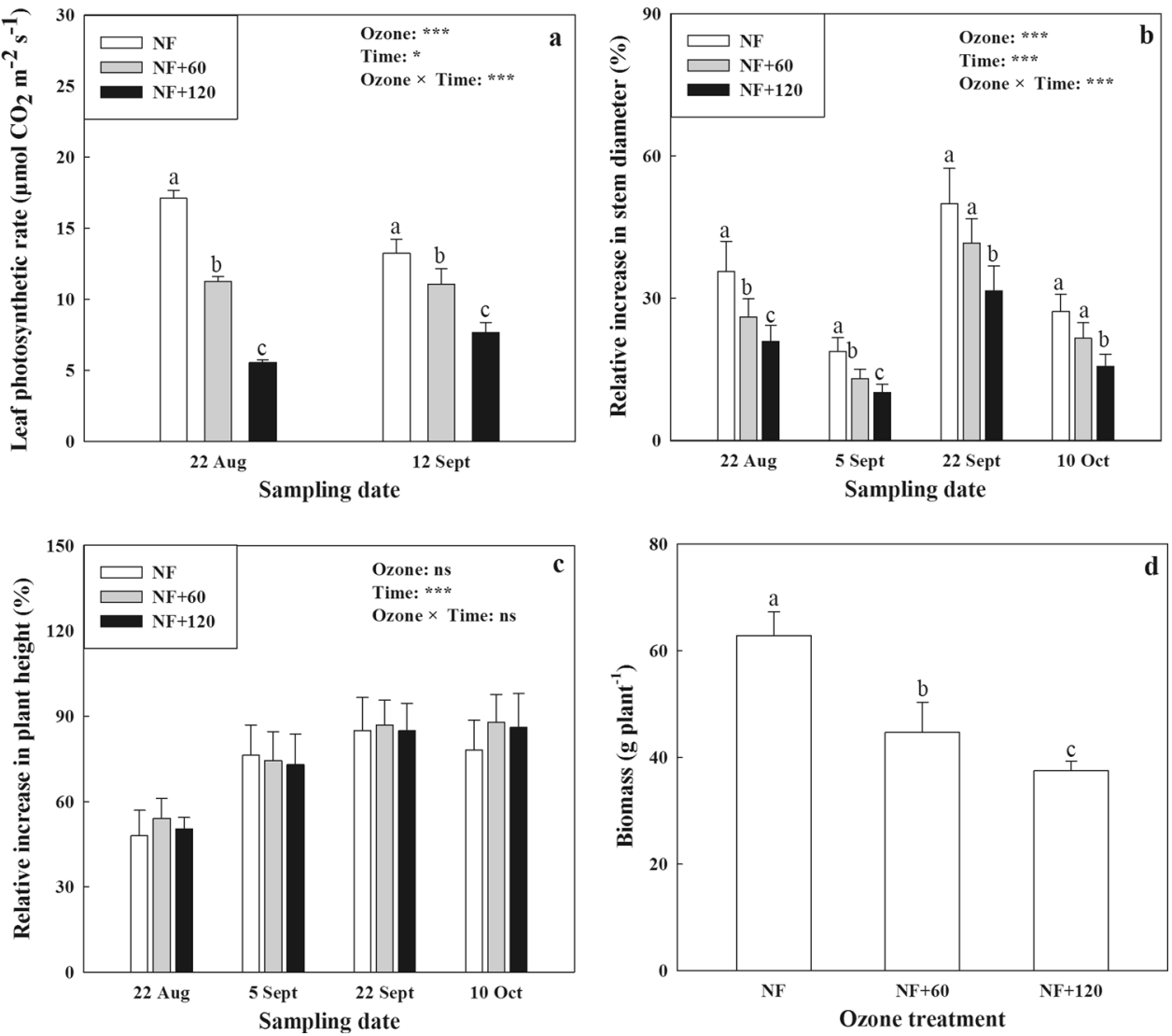

also induced oxidative damage to soluble proteins in marigold leaves at both the pre-anthesis and anthesis stages, with a decrease of $11.2-12.6 \%$ in protein content under $\mathrm{NF}+60$ treatment and 12.9-21.7\% under NF+120 treatment (Fig. 6b).

\section{Ascorbic acid system and jasmonic acid content}

Elevated $\mathrm{O}_{3}$ exposure promoted ASA synthesis and disturbed the ASA redox state (Fig. 7). The total ASA contents significantly increased throughout growth, with increases of 20.7-45.5\% under NF+60 treatment and $41.2-66.7 \%$ under $\mathrm{NF}+120$ treatment. However, the ASA redox state decreased, with $12.2-27.0 \%$ and $23.0-27.2 \%$ reductions under NF+60 and $\mathrm{NF}+120$ treatment, respectively. Additionally, elevated $\mathrm{O}_{3}$ exposure reduced JA content, with declines of 51.9-80.5\% under NF+60 treatment and of 75.9-78.8\% under NF+120 treatment compared with the control (Fig. 8).

\section{Discussion}

\section{Foliar injury and depression of plant growth by elevated $\mathrm{O}_{3}$}

The foliar injury symptoms in plant species are of major interest for realistically assessing the risks imposed by $\mathrm{O}_{3}$
(Furlan et al. 2007). In the current study, we found that elevated $\mathrm{O}_{3}$ levels accelerated the occurrence of leaf yellowing in marigold plants, which was first observed on the fifth day under NF+120 treatment (AOT40 $=6.4 \mathrm{ppm} \mathrm{h}$ ) and thirteenth day under NF+60 treatment $($ AOT $40=8.6$ ppm h). The results suggest that, in addition to AOT40 (Table 1), peak $\mathrm{O}_{3}$ has contributed to the development of foliar injury symptoms in marigold plants. As previously reported, plants respond more strongly to exposure to a higher peak $\mathrm{O}_{3}$ concentration (Musselman et al. 1983).

As a well-known pollutant, $\mathrm{O}_{3}$ has a negative impact on plant biomass due to the reduction in photosynthesis caused by the direct effect on light or dark reaction (Power and Ashmore 2002), or the indirect effect of stomatal conductance (Noormets et al. 2001). In the present study, $\mathrm{O}_{3}$ suppressed stomatal conductance, whereas the corresponding internal $\mathrm{CO}_{2}$ concentration tended to increase or remained constant at the control level $(271,301$, and 312 mmol mol ${ }^{-1}$ under NF, NF+60 and NF+120 treatments, respectively, at pre-anthesis; 300, 298, and $302 \mathrm{mmol}$ $\mathrm{mol}^{-1}$, respectively, at anthesis). A similar result was reported in Monarch birch by Watanabe et al. (2014), who indicated that decreased stomatal conductance is a passive response of plants to lower carboxylation efficiency, in order to maintain the ratio of intercellular to ambient $\mathrm{CO}_{2}$ concentration. We therefore speculate that increased $\mathrm{O}_{3}$ 
Fig. 5 Stomatal conductance (a 10:00 am-12:00 pm), stomatal aperture (b, 16:00 pm), stomatal density (c, 16:00 pm), and ozone flux (d, 10:00-12:00 pm) in leaves of marigold under different ozone levels.

Treatment abbreviations are as in Fig. 1. Data are shown as mean \pm standard error $\left(n_{\mathrm{a}}=n_{\mathrm{d}}\right.$ $\left.=5, n_{\mathrm{b}}=60, n_{\mathrm{c}}=20\right)$. For each parameter, results of one-way repeated measures ANOVA are reported, with asterisks showing the significance of factors (ozone and time) and their interaction for: $* * * P \leq 0.001$, $* * P \leq 0.01, * P \leq 0.05, \mathrm{~ns}=P>$ 0.05 . Different lowercase letters indicate significant differences between the ambient control (NF) and elevated $\mathrm{O}_{3}$ treatments $(\mathrm{NF}+60$ and $\mathrm{NF}+120)(P \leq 0.5)$
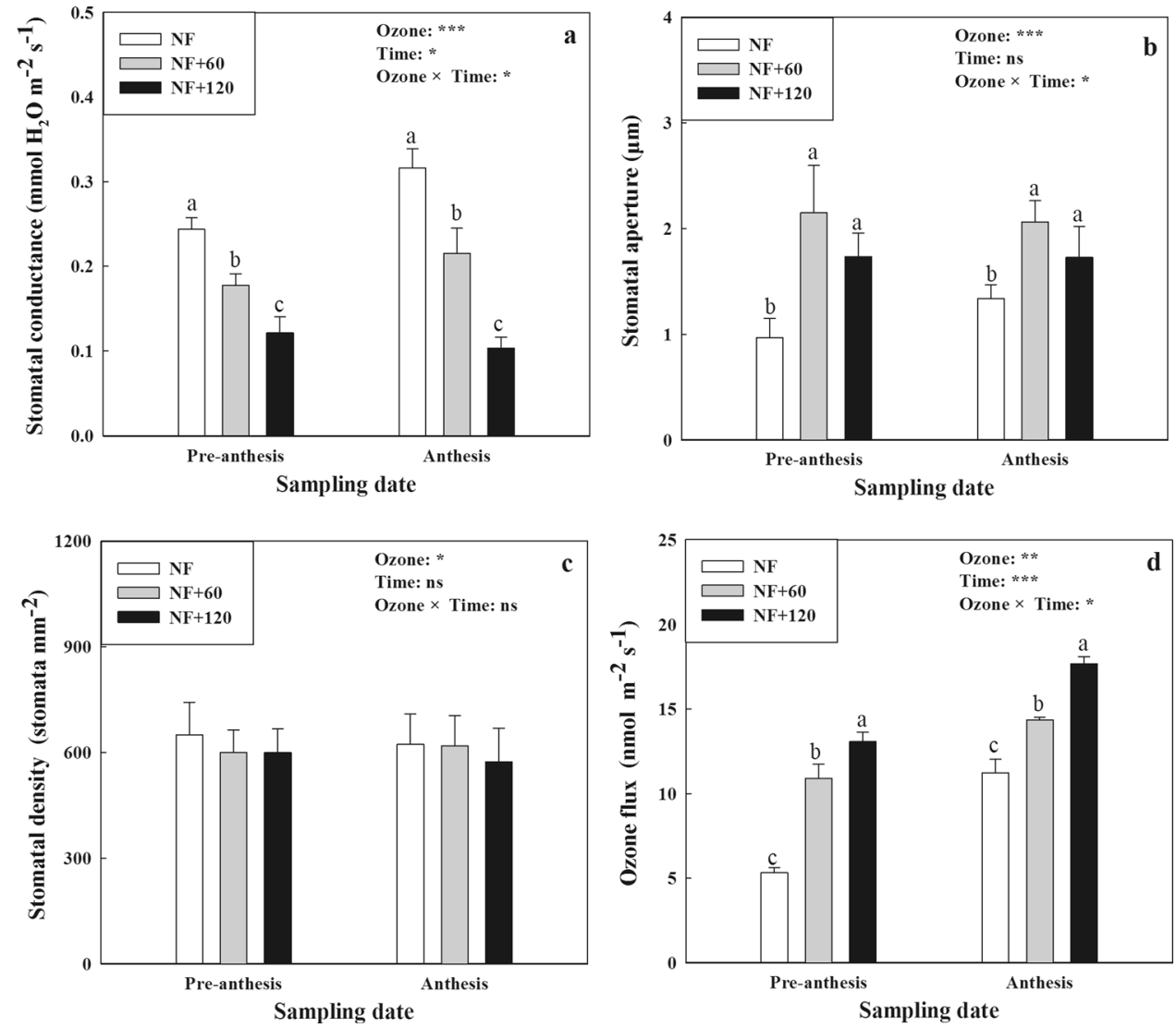

Fig. 6 Leaf malondialdehyde (MDA; a) and soluble protein (b) contents in leaves of marigold under different ozone levels. Treatment abbreviations are as in Fig. 1. Data are shown as mean \pm standard error $(n=5)$. For each parameter, results of one-way repeated measures ANOVA are reported, with asterisks showing the significance of factors (ozone and time) and their interaction for: $* * * P \leq 0.001, * * P \leq 0.01$, $* P \leq 0.05, \mathrm{~ns}=P>0.05$.

Different lowercase letters indicate significant differences between the ambient control (NF) and elevated $\mathrm{O}_{3}$ treatments $(\mathrm{NF}+60$ and $\mathrm{NF}+120)(P \leq 0.5)$
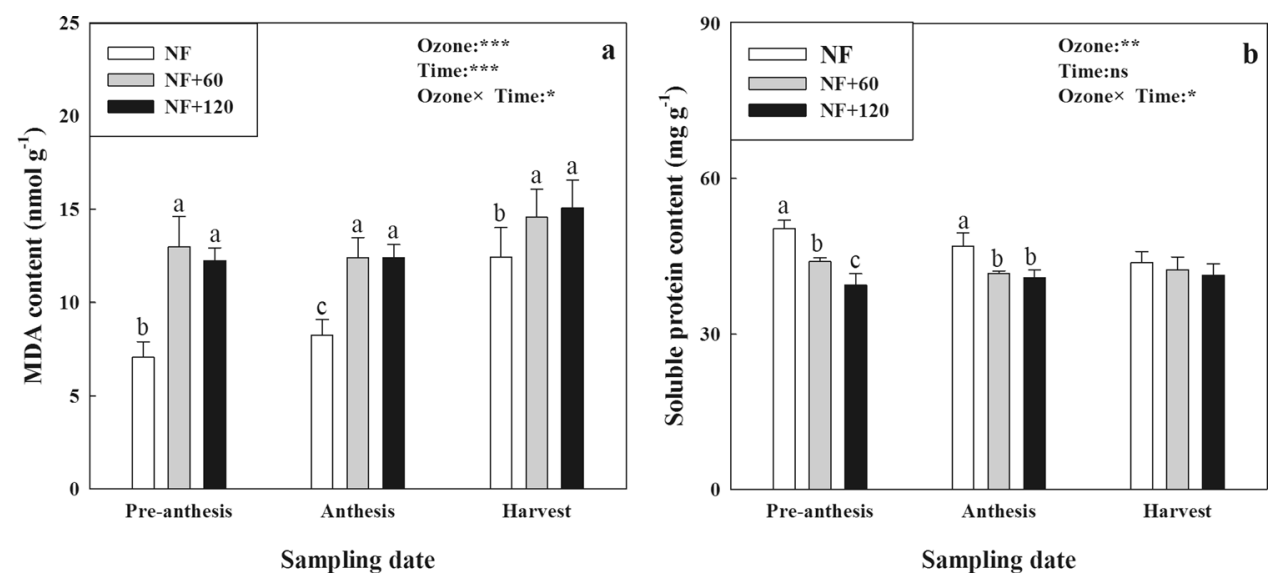

concentration decreased photosynthesis in marigold leaves by inhibiting light or dark reaction (reduced capability to take advantage of $\mathrm{CO}_{2}$ ), rather than $\mathrm{CO}_{2}$ diffusion from the atmosphere to the leaves.

Both stem diameter and plant height are major components of shoot architecture and are associated with biomass yield (Dubouzet et al. 2013; Okello et al. 2001). However, in the present study, reductions in marigold biomass were only accompanied by inhibited stem-diameter growth during the growing season. This result indicates that the reduction in stem diameter growth plays a more significant role in suppressing marigold biomass than changes in plant height. Previous work reported a similar response in poplar, Norway spruce, and European beech (single-stemmed plants) under high $\mathrm{O}_{3}$ environment, where stem diameter was inhibited more easily because $\mathrm{O}_{3}$ fumigation induced a 

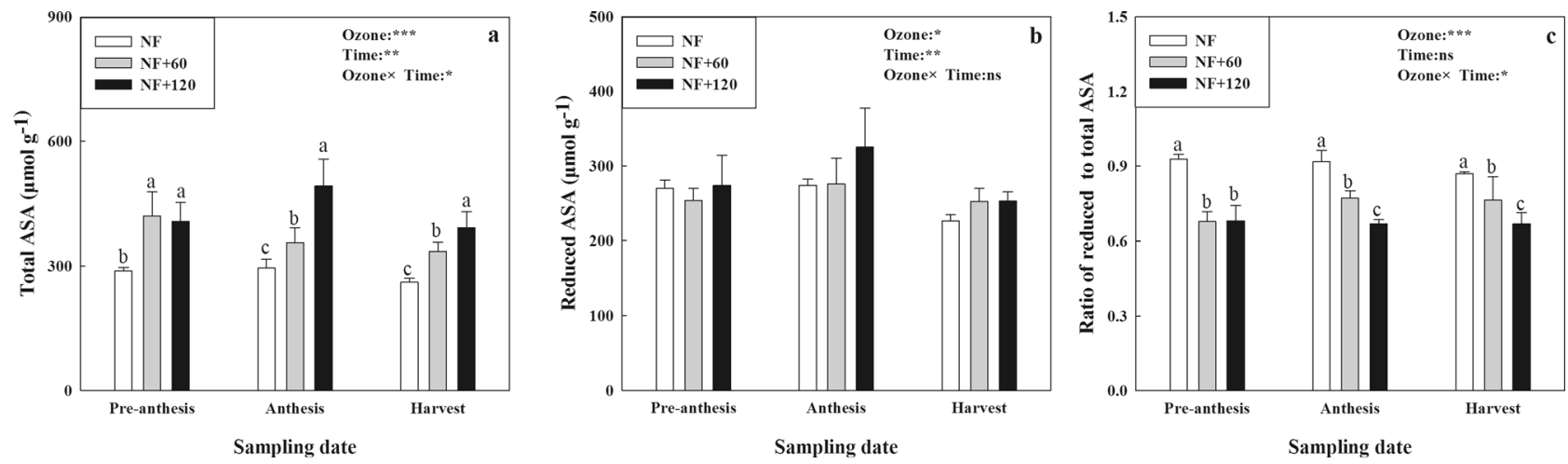

Fig. 7 Total ascorbic acid (ASA; a), reduced ASA (b) and the ratio of reduced to total ASA (c) in leaves of marigold under different ozone levels. Treatment abbreviations are as in Fig. 1. Data are shown as mean \pm standard error $(n=5)$. For each parameter, results of one-way repeated measures ANOVA are reported, with asterisks showing the

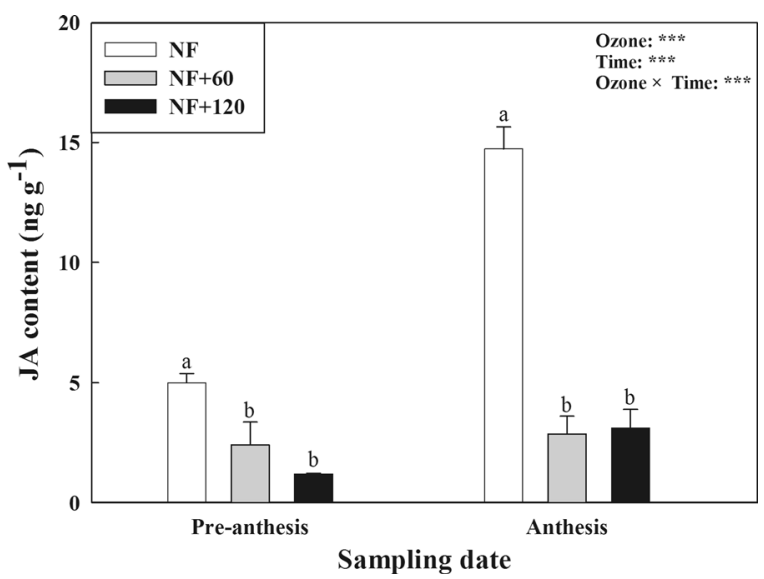

Fig. 8 Leaf jasmonic acid (JA) content in leaves of marigold under different ozone levels. Treatment abbreviations are as in Fig. 1. Data are shown as mean \pm standard error $(n=5)$. Results of one-way repeated measures ANOVA are reported, with asterisks showing the significance of factors (ozone and time) and their interaction for: $* * * P \leq 0.001$. Different lowercase letters indicate significant differences between the ambient control (NF) and elevated $\mathrm{O}_{3}$ treatments $(\mathrm{NF}+60$ and $\mathrm{NF}+120)(P \leq 0.5)$

shift in the resource allocation into height growth at the expense of diameter growth (Pretzsch et al. 2010; Carriero et al. 2015). $\mathrm{O}_{3}$-induced reductions in stem diameter could result in decreased stem stability and thus negatively affect the greening and ornamental values of marigold. Another important reason for the decline in marigold biomass is the increased percentage and severity of injured leaves (Fig. 3), which reduced the availability of healthy leaves for photosynthesis. Therefore, the increase in ground-level $\mathrm{O}_{3}$ concentration not only affected the ornamental value of marigold, but it also led to a loss of potential ecological benefits by inhibiting the formation of biomass.

While the $\mathrm{NF}+120$ treatment was a high $\mathrm{O}_{3}$ exposure, and represented the 'worst case' $\mathrm{O}_{3}$ exposure; in the present significance of factors (ozone and time) and their interaction for: $* * * P \leq 0.001, * * P \leq 0.01, * P \leq 0.05, \mathrm{~ns}=P>0.05$. Different lowercase letters indicate significant differences between ambient control $(\mathrm{NF})$ and elevated $\mathrm{O}_{3}$ treatments $(\mathrm{NF}+60$ and $\mathrm{NF}+120)(P \leq 0.5)$

study, plant growth responses to $\mathrm{NF}+120$ treatment were consistent with that to NF+60 treatment, and more severe in the former than the latter.

\section{Stomatal response to elevated $\mathrm{O}_{3}$ exposure}

In our experiment design, the responses of gas exchange and stomatal openness to $\mathrm{O}_{3}$ stress were measured separately: stomatal conductance was measured at about 11:00 a.m. in the morning when peak photosynthetic rate occurred using Li-6400 photosynthetic analyst; stomatal aperture was destructively measured at about 16:00 p.m. in the afternoon when the stomatal responses to $\mathrm{O}_{3}$ peak occurred.

Extensive studies have assessed the effects of $\mathrm{O}_{3}$ on stomatal movement due to its irreplaceable role in determining the rate of $\mathrm{O}_{3}$ uptake into leaves (Wilkinson and Davies 2010; Yamaguchi et al. 2014). Most reports indicate that $\mathrm{O}_{3}$ induces stomatal closure to protect plants from further injury through reduced $\mathrm{O}_{3}$ flux (Sun et al. 2014). Therefore, when guard cells are fully functional, the stomata can be regulated effectively to avoid $\mathrm{O}_{3}$ injury (Musselman and Minnick 2000). In the present study, elevated $\mathrm{O}_{3}$ treatment decreased the stomatal conductance of marigold leaves at both pre-anthesis and anthesis; this result is consistent with previous findings in deciduous trees, such as Fagus crenata, Fraxinus, Populus, and Prunus species (Hoshika et al. 2015; Wittig et al. 2007). However, the decline in stomatal conductance did not prevent injury to marigold by elevated $\mathrm{O}_{3}$, as shown by the significant decreases in biomass production and increased percentages of injured leaves.

The effects of $\mathrm{O}_{3}$ on plants depend on the amount of $\mathrm{O}_{3}$ entering the leaves and on the capacity of leaves for detoxification of $\mathrm{O}_{3}$ ( $\mathrm{Hu}$ et al. 2015; Musselman et al. 2006). $\mathrm{POD}_{\mathrm{Y}}$ (phytotoxic $\mathrm{O}_{3}$ dose over a threshold of $\mathrm{Y}$ ), 
an index based on $\mathrm{F}_{\mathrm{st}}$ ( (tomatal uptake rate of $\mathrm{O}_{3}$ ), has been widely used to indicate the critical levels of $\mathrm{O}_{3}$ needed to affect crops (Gonzalez-Fernandez et al. 2010), trees (Hu et al. 2015) and herbs (Danielsson et al. 2013). In the present study, the $\mathrm{O}_{3}$ flux into leaves increased under elevated $\mathrm{O}_{3}$ treatments compared with the control (Fig. 5d). By analyzing the correlation of $\mathrm{O}_{3}$ flux, $\mathrm{O}_{3}$ concentration, and stomatal conductance in smoke tree, rose, and marigold (data not shown), we concluded that $\mathrm{O}_{3}$ concentration, rather than stomatal conductance, is the predominant factor influencing $\mathrm{O}_{3}$ flux into leaves. Therefore, $\mathrm{O}_{3}$-induced reduction in stomatal conductance is likely the result of plant physiological response to elevated $\mathrm{O}_{3}$ exposure, but it is not an effective measure for reducing $\mathrm{O}_{3}$ injury due to high $\mathrm{O}_{3}$ concentrations (Sun et al. 2014).

Examination of stomatal ultrastructure showed that the stomatal aperture increased under elevated $\mathrm{O}_{3}$ exposure. This increase may be attributed to the following factors: (1) higher soluble sugar contents under $\mathrm{O}_{3}$ treatment (data not shown), as soluble sugar is a general osmolyte responsible for maintaining stomatal aperture (Lawson 2009); (2) inhibition of stomatal sensitivity to abscisic acid due to $\mathrm{O}_{3}$ induced ethylene production (Mills et al. 2009); (3) damage to the stomatal apparatus, as more $\mathrm{O}_{3}$ entered the substomatal cavities, which could injure the parenchyma and adjacent epidermal cells, followed by loss of cytoplasm; further, these changes could cause cell collapse and the functional loss of stomata (Hassan et al. 1994). The increase in stomatal aperture is proportional to the increase in pore depth, resulting in a longer diffusion path and thus increasing stomatal resistance (decreasing stomatal conductance) (Franks and Beerling 2009; Monda et al. 2016). In addition to stomatal aperture, stomatal density is another key factor affecting stomatal conductance (Franks and Beerling 2009). However, in the current study, no significant changes were detected in stomatal density in marigold plants under elevated $\mathrm{O}_{3}$ exposure. The above results suggest that, for "Moonsong Deep Orange", stomatal conductance may have a more closer relationship with stomatal aperture than density.

\section{Reduced ASA and its capacity to detoxify $\mathrm{O}_{3} / \mathrm{ROS}$ under elevated $\mathrm{O}_{3}$ exposure}

Stomata represent the first line of plant defense against $\mathrm{O}_{3}$ damage. As stomatal regulation alone cannot prevent $\mathrm{O}_{3}$ uptake, plants have developed an antioxidant system to alleviate $\mathrm{O}_{3}$ injury, including enzymatic and non-enzymatic antioxidants (Castagna and Ranieri 2009). Among the nonenzymatic ones, ASA is considered to be a major soluble antioxidant in photosynthetic tissue and it is thought to minimize the initial formation of ROS by $\mathrm{O}_{3}$ (ROS, e.g., hydrogen peroxide and superoxide) in the liquid phase of apoplast (Chaparzadeh et al. 2004; Booker et al. 2012). Plöchl et al. (2000) found that leaf ASA concentration is inversely related to $\mathrm{O}_{3}$ sensitivity. In the present study, although elevated $\mathrm{O}_{3}$ treatment significantly increased the total ASA content and tended to increase the levels of reduced $\mathrm{ASA}, \mathrm{O}_{3}$ injury was not alleviated in marigold leaves (Fig. 3). One possible reason for this result is that additional $\mathrm{O}_{3}$ was still present to attack the plasma membrane after reaction with ASA under elevated $\mathrm{O}_{3}$ treatment.

According to the literatures, approximately $10 \%$ of the ASA pool is localized within the apoplastic space (Conklin and Barth 2004; Eltayeb et al. 2006; Horemans et al. 2000b; Vanacker et al. 1998). The ratio of reduced to total ASA in apoplast varies with plant species in a wide range of 5-87\%, with an average of $45.1 \%$ (Booker et al. 2012; Luwe et al. 1993; Ranieri et al. 1996, 2000). If $0.2 \%$ of $\mathrm{O}_{3}$ flux can be decomposed by $2 \mu \mathrm{M}$ reduced ASA as suggested by Booker et al. (2012), the amount of $\mathrm{O}_{3}$ reacting with reduced ASA can be estimated by the equation: total ASA content $\times 10 \times$ $45 \% \times\left(0.2 \% / 2 \times \mathrm{O}_{3}\right.$ flux $)$. Here, the $\mathrm{O}_{3}$ flux represents the phytotoxic $\mathrm{O}_{3}$ dose over a threshold of $1\left(\mathrm{POD}_{1}\right)$ on the two measurement dates (pre-anthesis and anthesis). Therefore, the residual $\mathrm{O}_{3}$ level after reacting with ASA under NF, NF +60 , and NF+120 treatment was approximately 3.1, 6.2, and $6.9 \mathrm{mmol} \mathrm{m}^{-2}$ at pre-anthesis and 5.6, 9.1, and 8.5 $\mathrm{mmol} \mathrm{m}{ }^{-2}$ at anthesis, respectively. Only $1.0-2.0 \%$ of the accumulated $\mathrm{O}_{3}$ was reduced. Urbach et al. (1989) demonstrated that a major portion of the $\mathrm{O}_{3}$ pool is broken down inside the plasmalemma, damaging the biomembrane. However, the residual $\mathrm{O}_{3}$ amounts that may damage the plasmalemma were estimated based on the averaged percentage of the ratios of reduced ASA to total ASA in the apoplast from available reports (Booker et al. 2012; Luwe et al. 1993; Ranieri et al. 1996, 2000). In future studies, to accurately quantify the $\mathrm{O}_{3}$ amount reacting with ASA, direct measurement of reduced ASA in apoplast of marigold leaves will be required. Other antioxidants, i.e. enzymes and phenolics (Booker et al. 2012), can also detoxify $\mathrm{O}_{3}$ in protection against $\mathrm{O}_{3}$ injury to the plasmalemma. Thus, additional research is needed to investigate the relationship between these antioxidants and $\mathrm{O}_{3}$ injury.

The ASA redox state in $\mathrm{O}_{3}$-treated plants was disturbed, with 16.4-28.1 and 20.7-28.4\% reductions detected under $\mathrm{NF}+60$ and $\mathrm{NF}+120$ treatments, respectively. This process disrupts the homeostasis of the ASA pool, indicating the presence of a sensitive mechanism for the response to $\mathrm{O}_{3}$ stress (Horemans et al. 2000a). ASA flux across the plasmalemma is slower than $\mathrm{O}_{3}$ flux across the stomata (Luwe et al. 1993), which may have led to an irreversible reaction between $\mathrm{O}_{3}$ and other cellular components (e.g., biomembranes; Fig. 6) before ASA could detoxify $\mathrm{O}_{3}$ (Luwe et al. 1993). The toxicity of $\mathrm{O}_{3}$ is derived from the strong oxidizing capacity of both itself and its breakdown products, 
ROS. After reacting with reduced ASA, residual $\mathrm{O}_{3}$ and its breakdown products can come in contact with water, plasmalemma, or other cellular components, initiating subsequent cellular damage (Agrawal et al. 2002). In this study, we observed the effects of $\mathrm{O}_{3}$ levels that exceeded detoxification capacity in marigold leaves after elevated $\mathrm{O}_{3}$ exposure, even though the ASA contents were higher under elevated $\mathrm{O}_{3}$ treatment compared with the control. Higher ROS production could occur in the presence of more residual $\mathrm{O}_{3}$. It should be noted that ROS are produced as a normal product of plant cellular metabolism. In the normal environment, there is an equilibrium between ROS production and reduction. On this occasion, ROS act as secondary messengers regulating plants development, i.e., stomatal closure (Yan et al. 2007), root gravitropism (Joo et al. 2001), and conferment of tolerance to abiotic and biotic stresses (Miller et al. 2008). Elevated $\mathrm{O}_{3}$ exposure in the present study could lead to excessive production of ROS, exceeding the ROS-scavenging capacity of specific components and thus leading to injury to the plasma membrane. This process was documented by Singh et al. (2014), who found that the increase in $\mathrm{H}_{2} \mathrm{O}_{2}$ levels in stresstreated maize plants matched the increase in lipid peroxidation. Compared with the control, higher MDA levels appeared much earlier under elevated $\mathrm{O}_{3}$ exposure in this study, suggesting accelerated and aggravated leaf senescence in $\mathrm{O}_{3}$-treated marigold plants. Senescence is a timedependent stress response that occurs in all living organisms. Senescence can trigger the expression of autophagy genes and thus promote the autophagy, a critical pathway of protein degradation (Wang et al. 2013). Total protein concentrations decline in parallel with the senescence process (Wang et al. 2013). Additionally, the increase in lipid peroxidation can result in enhanced proteolysis (Moran et al. 1994). Therefore, soluble proteins are expected to degrade and their contents are expected to decline in marigold leaves under elevated $\mathrm{O}_{3}$ treatment. Ribulose 1,5-bisphosphate carboxylase (RuBisCO), an enzyme catalyzing photosynthetic $\mathrm{CO}_{2}$ fixation, accounts for half or more of the total soluble proteins, e.g., 50\% (Lin et al. 2014) to 70\% (Zheng et al. 2011b). The decline in soluble proteins indicates a possible decrease in $\mathrm{RuBisCO}$, which was expected to inhibit photosynthesis after elevated $\mathrm{O}_{3}$ exposure.

\section{Reduction in endogenous jasmonic acid levels under elevated $\mathrm{O}_{3}$ exposure and its implications for $\mathrm{O}_{3}$-induced injury}

As stated above, Elevated $\mathrm{O}_{3}$ exposure promoted plasmalemma peroxidation in marigold leaves, as expressed by increased MDA content. This suggests that the levels of accumulated ROS derived from $\mathrm{O}_{3}$ stress exceeded the ROS-scavenging capacity of specific cellular components, which could induce active production of additional ROS, called "second oxidative burst" (Burkey et al. 2006; Sawada et al. 2012). Increasing evidences indicate that ROS can affect plant growth, development, and productivity (Karuppanapandian et al. 2011). To limit ROS injury and to maintain growth, plants tend to increase their defenses against peroxidative stress by triggering the JA signaling pathway in response to plasmalemma peroxidation (Ren et al. 2015). In the present study, however, the JA contents decreased significantly in $\mathrm{O}_{3}$-treated marigold leaves, which is inconsistent with previous findings for other plants such as tomato and hybrid poplar (Koch et al. 2000; Ren et al. 2015). The decline in JA contents detected in the present study may be attributed to $\mathrm{O}_{3}$-induced chloroplast degradation (data not shown), as the chloroplast is the first site of JA biosynthesis (Bartoli et al. 2013). Oksanen et al. (2004) also reported that $\mathrm{O}_{3}$ significantly reduces chloroplast size in a sensitive aspen clone due to $\mathrm{H}_{2} \mathrm{O}_{2}$ accumulation. The breakdown of chloroplasts implies that the JA biosynthesis pathway is blocked, and a decrease in JA levels is therefore expected.

Jasmonic acid is considered to function antagonistically with ethylene by inhibiting the $\mathrm{O}_{3}$-induced biosynthesis of ethylene due to the conjugation of JA to the ethylene precursor 1-amino cyclopropane-1-carboxylic acid (Wasternack 2007), further containing the spread of ethylene-induced cell death (Cho et al. 2011). The decrease in JA levels may increase the release of 1-amino cyclopropane-1-carboxylic acid and thus the chance of cell death. Therefore, severe plant injury due to $\mathrm{O}_{3}$ stress was expected, as a reduction in endogenous JA levels contributed to the effects of $\mathrm{O}_{3}$ stress in marigold plants. JA also affects the normal growth of plants by regulating vegetative storage proteins (Creelman and Mullet 1997). Decreases in JA content indicate that fewer nutrients (especially nitrogen) are provided by vegetative storage proteins for the biosynthesis of novel proteins associated with plant defense responses (Beardmore et al. 2000; Staswick et al. 1991). Consequently, the levels of defensive enzymes that function downstream of the JA pathway are reduced (Ren et al. 2015). Therefore, the decrease in the protective ability of JA in the present study is thought to be a possible indirect reason for $\mathrm{O}_{3}$-induced injury to marigold leaves. This hypothesis can be supported by a study in Arabidopsis (Rao et al. 2000), which showed that JA-insensitive and JA-biosynthesis blocked mutants develop larger lesions than the one with the capacity to synthesize JA.

\section{Conclusions}

The results show that elevated $\mathrm{O}_{3}$ causes severe injury to 'Moonsong Deep Orange', as indicated by accelerated, 
pronounced leaf yellowing, as well as a significant decline in biomass production. The investigated cultivar of marigold therefore is a good bioindicator for $\mathrm{O}_{3}$. The response of marigold to elevated $\mathrm{O}_{3}$ is driven by complex physiological mechanisms: (1) Despite a reduction in stomatal conductance, $\mathrm{O}_{3}$ flux into leaves increased remarkably under elevated $\mathrm{O}_{3}$ exposure. The reduction in stomatal conductance is likely the result of plant physiological response to elevated $\mathrm{O}_{3}$ exposure, but it is not an effective measure for reducing $\mathrm{O}_{3}$ injury due to high $\mathrm{O}_{3}$ concentrations. (2) With increased $\mathrm{O}_{3}$ flux entering leaves, there were no significant changes in the content of reduced ASA after elevated $\mathrm{O}_{3}$ exposure. Thus, the existing reduced ASA may be insufficient to eliminate additional $\mathrm{O}_{3}$ and/or its breakdown products ROS under elevated $\mathrm{O}_{3}$ exposure. (3) Disturbed ASA redox state (decreased ratio of reduced to total ASA) provides a sensitive mechanism for the response to $\mathrm{O}_{3}$ stress. (4) The protective effects of JA on plants may be weakened after elevated $\mathrm{O}_{3}$ exposure due to decreased capacity of leaves to synthesize JA.

Acknowledgements This study was supported by the National Natural Science Foundation of China (No. 31200295). We thank Yulong Zhang from the State Key Laboratory of Urban and Regional Ecology, Research Center for Eco-Environmental Sciences, for assistance in building the infrastructure for $\mathrm{O}_{3}$ fumigation and sample collection. We also thank Xu Sun from Beijing Urban Ecosystem Research Station, Research Center for Eco-Environmental Sciences, for providing background data of ambient $\mathrm{SO}_{2}$ and $\mathrm{NO}_{2}$ concentrations.

Funding This study was funded by the National Natural Science Foundation of China (No. 31200295)

\section{Compliance with ethical standards}

Conflict of interest Ning Yang declares that she has no conflict of interest. Xiaoke Wang declares that he has no conflict of interest. Feixiang Zheng declares that he has no conflict of interest. Yuanyuan Chen declares that she has no conflict of interest.

Ethical approval This article does not contain any studies with human participants or animal performed by any of authors.

\section{Reference}

Agrawal GK, Rakwal R, Yonekura M, Kubo A, Saji H (2002) Proteome analysis of differentially displayed proteins as a tool for investigating ozone stress in rice (Oryza sativa L.) seedlings. Proteomics 2:947-959

Ainsworth E, Yendrek C, Sitch S, Collins W, Emberson L (2012) The effects of tropospheric ozone on net primary productivity and implications for climate change. Annu Rev Plant Biol 63: 637-661

Ashmore M (2005) Assessing the future global impacts of ozone on vegetation. Plant Cell Environ 28:949-964
Baier M, Kandlbinder A, Golldack D, Dietz KJ (2005) Oxidative stress and ozone: Perception, signalling and response. Plant Cell Environ 28:1012-1020

Bao X, Li Q, Hua J, Zhao T, Liang W (2014) Interactive effects of elevated ozone and UV-B radiation on soil nematode diversity. Ecotoxicology 23:11-20

Bartoli CG, Casalongué CA, Simontacchi M, Marquez-Garcia B, Foyer $\mathrm{CH}$ (2013) Interactions between hormone and redox signalling pathways in the control of growth and cross tolerance to stress. Environ Exp Bot 94:73-88

Beardmore T, Wetzel S, Kalous M (2000) Interactions of airborne methyl jasmonate with vegetative storage protein gene and protein accumulation and biomass partitioning in Populus plants. Can J Forest Res 30:1106-1113

Booker FL, Burkey KO, Jones AM (2012) Re-evaluating the role of ascorbic acid and phenolic glycosides in ozone scavenging in the leaf apoplast of Arabidopsis thaliana L. Plant Cell Environ 35:1456-1466

Bradford MM (1976) A rapid and sensitive method for the quantitation of microgram quantities of protein utilizing the principle of protein-dye binding. Anal Biochem 72:248-254. doi:10.1016/ 0003-2697(76)90527-3

Broadmeadow M (1998) Ozone and forest trees. New Phytol 139: $123-125$

Burkey KO, Neufeld HS, Souza L, Chappelka AH, Davison AW (2006) Seasonal profiles of leaf ascorbic acid content and redox state in ozone-sensitive wildflowers. Environ Pollut 143: 427-434. doi:10.1016/j.envpol.2005.12.009

Carriero G, Emiliani G, Giovannelli A, Hoshika Y, Manning WJ, Traversi ML, Paoletti E (2015) Effects of long-term ambient ozone exposure on biomass and wood traits in poplar treated with ethylenediurea (EDU). Environ Pollut 206:575-581

Castagna A, Ranieri A (2009) Detoxification and repair process of ozone injury: From $\mathrm{O}_{3}$ uptake to gene expression adjustment. Environ Pollut 157:1461-1469

Chaparzadeh N, D'Amico ML, Khavari-Nejad R-A, Izzo R, Navari-Izzo F (2004) Antioxidative responses of Calendula officinalis under salinity conditions. Plant Physiol Bioch 42:695-701. doi:10.1016/j.plaphy.2004.07.001

Chen W, Tang H, Zhao H (2015) Durnal, weekly and monthly spatial variations of air pollutants and air quality of Beijing. Atmons Environ 119:21-34

Cho K et al. (2011) Tropospheric ozone and plants: absorption, responses, and consequences. In: Whitacre DM (ed) Reviews of Environmental Contamination and Toxicology, Volume 212. Springer, USA, pp 61-111

Conklin PL, Barth C (2004) Ascorbic acid, a familiar small molecule intertwined in the response of plants to ozone, pathogens, and the onset of senescence. Plant Cell Environ 27:959-970. doi:10. 1111/j.1365-3040.2004.01203.x

Creelman RA, Mullet JE (1997) Biosynthesis and action of jasmonates in plants. Annu Rev Plant Biol 48:355-381

Danielsson H, Karlsson PE, Pleijel H (2013) An ozone response relationship for four Phleum pratense genotypes based on modelling of the phytotoxic ozone dose (POD). Environ Exp Bot 90:70-77

Dasgupta N, Ranjan S, Saha P, Jain R, Malhotra S, Mohamed Saleh MAA (2012) Antibacterial activity of leaf extract of Mexican marigold (Tagetes erecta) against different Gram positive and Gram negative bacterial strains. J Pharm Res 5: 4201-4203

Dubouzet JG, Strabala TJ, Wagner A (2013) Potential transgenic routes to increase tree biomass. Plant Sci 212:72-101. doi:10. 1016/j.plantsci.2013.08.006

Eltayeb AE, Kawano N, Badawi GH, Kaminaka H, Sanekata T, Morishima I, Shibahara T, Inanaga S, Tanaka K (2006) Enhanced 
tolerance to ozone and drought stresses in transgenic tobacco overexpressing dehydroascorbate reductase in cytosol. Physiol Plant 127:57-65

Evans PA, Ashmore MR (1992) The effects of ambient air on a seminatural grassland community. Agric Ecosyst Environ 38:91-97. doi:10.1016/0167-8809(92)90170-G

Fares S, Savi F, Muller J, Matteucci G, Paoletti E (2014) Simultaneous measurements of above and below canopy ozone fluxes help partitioning ozone deposition between its various sinks in a Mediterranean Oak Forest. Agr Forest Meteorol 198:181-191

Feng Z, Niu J, Zhang W, Wang X, Yao F, Tian Y (2011a) Effects of ozone exposure on sub-tropical evergreen Cinnamomum camphora seedlings grown in different nitrogen loads. Trees 25:617-625

Feng Z, Pang J, Kobayashi K, Zhu J, Ort DR (2011b) Differential responses in two varieties of winter wheat to elevated ozone concentration under fully open-air field conditions. Global Change Biol 17:580-591. doi:10.1111/j.1365-2486.2010.02184.x

Franks PJ, Beerling DJ (2009) Maximum leaf conductance driven by $\mathrm{CO}_{2}$ effects on stomatal size and density over geologic time. PNAS 106(25):10343-10347

Frey B, Scheidegger C, Günthardt-Goerg MS, Matyssek R (1996) The effects of ozone and nutrient supply on stomatal response in birch (Betula pendula) leaves as determined by digital image-analysis and X-ray microanalysis. New Phytol 132:135-143

Furlan CM, Moraes RM, Bulbovas P, Domingos M, Salatino A, Sanz MJ (2007) Psidium guajava 'Paluma' (the guava plant) as a new bio-indicator of ozone in the tropics. Environ Pollut 147: 691-695. doi:10.1016/j.envpol.2006.09.014

Gillespie KM, Ainsworth EA (2007) Measurement of reduced, oxidized and total ascorbate content in plants. Nat Protoc 2:871-874

Gonzalez-Fernandez I, Kaminska A, Dodmani M, Goumenaki E, Quarrie S, Barnes JD (2010) Establishing ozone flux eresponse relationships for winter wheat: analysis of uncertainties based on data for UK and Polish genotypes. Atmos Environ 44:6217630

Grantz D, Vu H-B, Heath R, Burkey K (2013) Demonstration of a diel trend in sensitivity of Gossypium to ozone: a step toward relating $\mathrm{O} 3$ injury to exposure or flux. J Exp Bot 64:1703-1713

Hassan IA, Ashmore MR, Bell JNB (1994) Effects of $\mathrm{O}_{3}$ on the stomatal behaviour of Egyptian varieties of radish (Raphanus sativus L. cv. Baladey) and turnip (Brassica rapa L. cv. Sultani). New Phytol 128:243-249

Horemans N, Foyer CH, Asard H (2000a) Transport and action of ascorbate at the plant plasma membrane. Trends Plant Sci 5:263-267. doi:10.1016/S1360-1385(00)01649-6

Horemans N, Foyer CH, Potters G, Asard H (2000b) Ascorbate function and associated transport system in plants. Plant Physiol Biochem 38:531-540

Hoshika Y, Carriero G, Feng Z, Zhang Y, Paoletti E (2014) Determinants of stomatal sluggishness in ozone-exposed deciduous tree species. Sci Total Environ 481:453-458. doi:10.1016/j. scitotenv.2014.02.080

Hoshika Y, Watanabe M, Kitao M, Häberle K-H, Grams TEE, Koike $\mathrm{T}$, Matyssek R (2015) Ozone induces stomatal narrowing in European and Siebold's beeches: A comparison between two experiments of free-air ozone exposure. Environ Pollut 196:527-533. doi:10.1016/j.envpol.2014.07.034

Hu E, Gao F, Xin Y, Jia H, Li K, Hu J, Feng Z (2015) Concentrationand flux-based ozone dose-response relationships for five poplar clones grown in North China. Environ Pollut 207:21-30

Hussain MA, Mukhtar T, Kayani MZ (2011) Efficacy evaluation of Azadirachta indica, Calotropis procera, Datura stramonium and Tagetes erecta against root-knot nematodes Meloidogyne incognita. Pak J Bot 43:197-204

ICPP IPoCC (2013) Fifth assessment report, http://www.icpp.ch/ report/ar5/index.shtml
Joo JH, Bae YS, Lee JS (2001) Role of Auxin-induced reactive oxygen species in root gravitropism. Plant Physiol 126(3): $1055-1060$

Karuppanapandian T, Moon J-C, Kim C, Manoharan K, Kim W (2011) Reactive oxygen species in plants: their generation, signal transduction, and scavenging mechanisms. Aust J Crop Sci 5(6): 709-725

Kiranmai M, Kazim SM, Ibrahim M (2011) Combined wound healing activity of Gymnema sylvestre and Tagetes erecta linn. Int J Pharm Appl 2:135-140

Koch JR, Creelman RA, Eshita SM, Seskar M, Mullet JE, Davis KR (2000) Ozone sensitivity in hybrid poplar correlates with insensitivity to both salicylic acid and jasmonic acid. The role of programmed cell death in lesion formation. Plant Phys 123:487-496. doi:10.1104/pp.123.2.487

Lawson T (2009) Guard cell photosynthesis and stomatal function. New Phytol 181:13-34

Lin MT, Occhialini A, Andralojc PJ, Parry MA, Hanson MR (2014) A faster Rubisco with potential to increase photosynthesis in crops. Nature 513:547-550

Luwe MW, Takahama U, Heber U (1993) Role of ascorbate in detoxifying ozone in the apoplast of spinach (Spinacia oleracea L.) leaves. Plant Physiol 101:969-976

Maity N, Nema NK, Abedy MK, Sarkar BK, Mukherjee PK (2011) Exploring Tagetes erecta Linn flower for the elastase, hyaluronidase and MMP-1 inhibitory activity. J Ethnopharmacol 137:1300-1305

Miller G, Shulaev V, Mittler R (2008) Reactive oxygen signaling and abiotic stress. Physiol Plantarum 133:481-489

Mills G, Hayes F, Wilkinson S, Davies WJ (2009) Chronic exposure to increasing background ozone impairs stomatal functioning in grassland species. Global Change Biol 15:1522-1533

Monda K, Araki H, Kuhara S, Ishigaki G, Akashi R, Negi J, Kojima M, Sakakibara H, Takahashi S, Hashimoto-Sugimoto M (2016) Enhanced stomatal conductance by a spontaneous Arabidopsis Tetraploid, Me- 0 , results from increased stomatal size and greater stomatal aperture. Plant Physiol 170:1435-1444

Moran JF, Becana M, Iturbe-Ormaetxe I, Frechilla S, Klucas RV, Aparicio-Tejo P (1994) Drought induces oxidative stress in pea plants. Planta 194:346-352

Musselman RC, Lefohn AS, Massman WJ, Heath RL (2006) A critical review and analysis of the use of exposure- and flux-based ozone indices for predicting vegetation effects. Atmos Environ 40(10): $1869-1888$

Musselman RC, Minnick TJ (2000) Nocturnal stomatal conductance and ambient air quality standards for ozone. Atmos Environ 34:719-733. doi:10.1016/S1352-2310(99)00355-6

Musselman RC, Oshima RJ, Gallavan RE (1983) Significance of pollutant concentration distribution in the response of "red kidney" beans to ozone. J Am Soc Hortic Sci 108(2):347-351

Nikkon F, Habib MR, Saud ZA, Karim MR (2011) Tagetes erecta Linn. and its mosquitocidal potency against Culex quinquefasciatus. Asian Pac J Trop Biomed 1:186-188

Noormets A, Sober A, Pell E, Dickson R, Podila G, Sober J, Isebrands J, Karnosky D (2001) Stomatal and non-stomatal limitation to photosynthesis in two trembling aspen (Populus tremuloides Michx.) clones exposed to elevated $\mathrm{CO}_{2}$ and/or $\mathrm{O}_{3}$. Plant Cell Environ 24:327-336

Okello BD, O'Connor TG, Young TP (2001) Growth, biomass estimates, and charcoal production of Acacia drepanolobium in Laikipia, Kenya. Forest Ecol Manag 142:143-153. doi:10.1016/ S0378-1127(00)00346-7

Oksanen E, Häikiö E, Sober J, Karnosky D (2004) Ozone-induced $\mathrm{H}_{2} \mathrm{O}_{2}$ accumulation in field-grown aspen and birch is linked to foliar ultrastructure and peroxisomal activity. New Phytol 161: 791-799 
Pääkkönen E, Metsärinne S, Holopainen T, Kärenlampi L (1996) The ozone sensitivity of birch (Betula pendula) in relation to the developmental stage of leaves. New Phytol 132:145-154

Pan X, Welti R, Wang X (2010) Quantitative analysis of major plant hormones in crude plant extracts by high-performance liquid chromatography-mass spectrometry. Nat Protoc 5:986-992. doi:10.1038/nprot.2010.37

Pellegrini E, Trivellini A, Campanella A, Francini A, Lorenzini G, Nali C, Vernieri P (2013) Signaling molecules and cell death in Melissa officinalis plants exposed to ozone. Plant Cell Rep 32:1965-1980

Plöchl M, Lyons T, Ollerenshaw J, Barnes J (2000) Simulating ozone detoxification in the leaf apoplast through the direct reaction with ascorbate. Planta 210:454-467. doi:10.1007/PL00008153

Power S, Ashmore M (2002) Responses of fen and fen-meadow communities to ozone. New Phytol 156:399-408

Pretzsch H, Dieler J, Matysse R, Wipfler P (2010) Tree and stand growth of mature Norway spruce and European beech under long-term ozone fumigation. Environ Pollut 158:1061-1070

Ranieri A, D’Urso G, Nali C, Lorenzini G, Soldatini G (1996) Ozone stimulates apoplastic antioxidant systems in pumpkin leaves. Physiol Plantarum 97:381-387

Ranieri A, Petacco F, Castagna A, Soldatini GF (2000) Redox status and peroxidase system in sunflower plants exposed to ozone. Plant Sci 159:159-167

Rao MV, Lee H-i, Creelman RA, Mullet JE, Davis KR (2000) Jasmonic acid signaling modulates ozone-induced hypersensitive cell death. Plant Cell 12:1633-1646

Reinert RA, Sanders JS (1982) Growth of radish and marigold following repeated exposure to nitrogen dioxide, sulfur dioxide, and ozone. Plant Dis 66(2):122-124

Ren Q, Sun Y, Guo H, Wang C, Li C, Ge F (2015) Elevated ozone induces jasmonic acid defense of tomato plants and reduces midgut proteinase activity in Helicoverpa armigera. Entomol Exp Appl 154:188-198

Sanders JS, Reinert RA (1982) Weight changes to radish and marigold exposed at three ages to $\mathrm{NO}_{2}, \mathrm{SO}_{2}$ and $\mathrm{O}_{3}$ alone and in mixture. J Am Soc Hortic Sci 107(4):726-730

Sawada H, Komatsu S, Nanjo Y, Khan NA, Kohno Y (2012) Proteomic analysis of rice response involved in reduction of grain yield under elevated ozone stress. Environ Exp Bot 77:108-116. doi:10.1016/j.envexpbot.2011.11.009

Singh AA, Agrawal S, Shahi J, Agrawal M (2014) Investigating the response of tropical maize (Zea mays L.) cultivars against elevated levels of $\mathrm{O}_{3}$ at two developmental stages. Ecotoxicology 23:1447-1463

Staswick PE, Huang J-F, Rhee Y (1991) Nitrogen and methyl jasmonate induction of soybean vegetative storage protein genes. Plant Physiol 96:130-136

Sun J, Feng Z, Ort DR (2014) Impacts of rising tropospheric ozone on photosynthesis and metabolite levels on field grown soybean. Plant Sci 226:147-161

Urbach W, Schmidt W, Kolbowski J, Rümmele S, Reisberg E, Steigner W, Schreiber U (1989) Wirkungen von Umweltschadstoffen auf Photosynthese und Zellmembranen von Pflanzen GSF-Bericht (Germany)
Vanacker H, Carver TLW, Foyer CH (1998) Pathogen-induced changes in the antioxidant status of the apoplast in barley leaves. Plant Physiol 117:1103-1114

Vingarzan R (2004) A review of surface ozone background levels and trends. Atmos Environ 38:3431-3442. doi:10.1016/j.atmosenv. 2004.03.030

Watanabe M, Hoshika Y, Koike T (2014) Photosynthetic responses of Monarch birch seedlings to differing timings of free air ozone fumigation. J Plant Res 127:339-345

Wang P, Sun X, Chang C, Feng F, Liang D, Cheng L, Ma F (2013) Delay in leaf senescence of Malus hupehensis by long-term melatonin application is associated with its regulation of metabolic status and protein degradation. Journal of Pineal Res 55:424-434

Wasternack C (2007) Jasmonates: an update on biosynthesis, signal transduction and action in plant stress response, growth and development. Ann Bot 100:681-697. doi:10.1093/aob/mcm079

Wasternack C (2014) Action of jasmonates in plant stress responses and development-Applied aspects. Biotechnol Adv 32:31-39. doi:10.1016/j.biotechadv.2013.09.009

Wen Z, Wang L, Wang X, Li 1, Cui J (2014) Combined effects of ozone and drought on leaf stomata of Acer truncatum (in Chinese with English abstract). Chin J Ecol 33:560-566

Wilkinson S, Davies WJ (2010) Drought, ozone, ABA and ethylene: new insights from cell to plant to community. Plant Cell Environ 33:510-525

Wittig VE, Ainsworth EA, Long SP (2007) To what extent do current and projected increases in surface ozone affect photosynthesis and stomatal conductance of trees? A meta-analytic review of the last 3 decades of experiments. Plant Cell Environ 30:1150-1162

Yamaguchi M, Hoshino D, Inada H, Akhtar N, Sumioka C, Takeda K, Izuta $T$ (2014) Evaluation of the effects of ozone on yield of Japanese rice (Oryza sativa L.) based on stomatal ozone uptake. Environ Pollut 184:472-480. doi:10.1016/j.envpol.2013.09.024

Yan J, Tsuichihara N, Etoh T, Iwai S (2007) Reactive oxygen species and nitric oxide are involved in ABA inhibition of stomatal opening. Plant Cell Environ 30:1320-1325

Zhang S, Gao R (1999) Diurnal changes of gas exchange, chlorophyll fluorescence, and stomatal aperture of hybrid poplar clones subjected to midday light stress. Photosynthetica 37(4):559-571

Zhang WW, Niu JF, Wang XK, Tian Y, Yao FF, Feng ZZ (2011) Effects of ozone exposure on growth and photosynthesis of the seedlings of Liriodendron chinense (Hemsl.) Sarg, a native tree species of subtropical China. Photosynthetica 49:29-36. doi:10. 1007/s11099-011-0003-5

Zhao T, Liu B, Wang Y, Zhao Y, Liu Y, Guo W (2013) Effects of ozone stress on soybean roots endogenous hormones and reactive oxygen metabolism (in Chinese with English abstract). Agric Res Arid Areas 31:119-123

Zheng F, Wang X, Lu F, Hou P, Zhang W, Duan X, Zhou X, Ai Y, Zheng H, Ouyang Z (2011a) Effects of elevated ozone concentration on methane emission from a rice paddy in Yangtze River Delta, China. Global Change Biol 17:898-910

Zheng Y, Li Y, Xia W, Xu H, Su B, Jiang G, Ning T (2011b) Responses of gas exchange, cellular membrane integrity, and antioxidant enzymes activities of salinity-stressed winter wheat to ozone pollution. Photosynthetica 49:389-396 